\title{
Polymerase chain reaction for the detection of Bordetella pertussis in clinical nasopharyngeal aspirates
}

\author{
P. MASTRANTONIO, P. STEFANELLI and M. GIULIANO
}

Department of Bacteriology and Medical Mycology, Istituto Superiore di Sanità, Viale Regina Elena 299, 00161 Rome, Italy

\begin{abstract}
A PCR procedure for the detection of Bordetella pertussis in nasopharyngeal aspirates (NPAs) was developed with primers derived from the pertussis toxin promoter region. The amplification resulted in a 191-bp PCR product specific for $B$. pertussis. A total of 681 NPAs collected from children with cough lasting $>7$ days was evaluated by PCR and culture; 104 aspirates were positive by PCR and 93 by culture. Sixteen cases were positive only by PCR and five culture positive aspirates were negative by PCR. An internal control was included in the assay to monitor the performance of the PCR and to identify possible inhibitory components in clinical samples. The PCR method was more efficient than culture in detecting $B$. pertussis in samples collected late in the disease, in antibiotic-treated children and in patients with mild disease.
\end{abstract}

\section{Introduction}

A crucial problem for the study of the epidemiology of pertussis is the lack of a sensitive and rapid laboratory method to diagnose the disease, especially when mild or atypical clinical symptoms are present. The isolation of Bordetella pertussis from the nasopharyngeal secretions of suspected patients is still considered to be the gold standard [1]. However, bacteriological diagnosis has low sensitivity as $B$. pertussis is a fastidious micro-organism, patients often have been treated with antibiotics and bacteria are cleared rapidly from the nasopharynx. It has been reported that the isolation rate varies between $60 \%$ and $6 \%$, depending on the stage of the disease [2]. On the other hand, the serological determination of specific antibodies needs two serum samples collected during the acute and convalescent phases and, therefore, may delay the diagnosis [1, 3-5].

In recent years, the polymerase chain reaction (PCR) has been used in a number of studies to identify $B$. pertussis directly from nasopharyngeal secretions [616]. Different regions in $B$. pertussis DNA, such as a repeated insertion sequence, the adenylate cyclase toxin gene, the DNA upstream of the porin gene and the pertussis toxin promoter have been evaluated as specific PCR targets $[6-9,17]$.

Received 2 June 1995; revised version accepted 30 July 1995.

Corresponding author: Dr P. Mastrantonio.
In Italy, a clinical trial for the evaluation of acellular pertussis vaccines was performed from 1992 to the end of 1994. This study included the clinical and microbiological follow-up of 15000 children and represented an excellent opportunity to evaluate the role of PCR in the diagnosis of pertussis [18]. PCR was used to amplify a 191-bp sequence of the pertussis toxin promoter, as reported previously by Houard et al. [8]. This sequence corresponds to a DNA region that is conserved in all strains of $B$. pertussis but contains a cluster of mutations in the other two related species, B. parapertussis and B. bronchiseptica [19-21]. A total of 681 nasopharyngeal aspirates (NPAs) from symptomatic children was tested in parallel by PCR and culture. The use of an internal control to monitor the performance of the PCR assay was also evaluated.

\section{Materials and methods}

Patients and sampling

The specimens were obtained between December 1992 and September 1994 from children with cough lasting $>7$ days, and participating in the Italian trial on the efficacy of acellular pertussis vaccines. The NPAs were collected with a De Lee suction catheter (Sherwood Medical, St Louis, MO, USA). The tip of the catheter was immediately streaked on charcoal agar supplemented with defibrinated horse blood $10 \%$ and cephalexin $20 \mu \mathrm{g} / \mathrm{ml}$ (22) (Unipath). The catheter was then flushed with $1 \mathrm{ml}$ of PBS and the aspirate was collected in a plastic trap. Plates and aspirates were 
then delivered to the laboratory. Details of clinical characteristics were collected for each child.

\section{Culture}

In the laboratory, the NPAs $(50 \mu \mathrm{l})$ were immediately cultured on selective charcoal agar plates which were incubated together with the previously streaked plates at $35^{\circ} \mathrm{C}$ in a moist atmosphere. Plates were examined for up to 7 days for growth of typical colonies. Suspected B. pertussis colonies on either plate were identified by biochemical tests and agglutination with specific antisera (Murex Diagnostics Ltd). After culturing, the aspirates were stored at $-80^{\circ} \mathrm{C}$ until analysis by PCR.

\section{Bacterial strains}

To assess the sensitivity and the specificity of the primers used in the PCR, 82 clinical and three reference strains were tested (Table 1). The American Type Culture Collection (ATCC) reference strains were B. pertussis ATCC 9797 (18-323), B. parapertussis ATCC 9305 and B. bronchiseptica ATCC 4617. Bordetellae, grown for $48 \mathrm{~h}$ on supplemented charcoal agar and the other bacteria cultured on routinely used media, were suspended in $1 \mathrm{ml}$ of distilled water, heated for $10 \mathrm{~min}$ at $100^{\circ} \mathrm{C}$ and tested at a concentration of $c .10^{4}$ cells/reaction.

\section{Sample preparation for PCR}

Frozen NPAs were thawed at room temperature and $50 \mu \mathrm{l}$ of the sample were digested for $1 \mathrm{~h}$ at $65^{\circ} \mathrm{C}$ with proteinase $\mathrm{K}$ (Boehringer Mannheim, Germany) $0.2 \mu \mathrm{g} / \mathrm{ml}$ in Tris- $\mathrm{HCl}, \mathrm{pH} 7.6$ [7] and then heat inactivated at $100^{\circ} \mathrm{C}$ for $20 \mathrm{~min}$. Twenty $\mu \mathrm{l}$ of Chelex 100 (BioRad, Milan, Italy) were then added to each mixture. This weak anion exchange resin has been reported to remove cations which are possible inhibitors of Taq polymerase [23].

\section{Primers}

A set of primers derived from the pertussis toxin operon [8] was chosen and synthesised on an automated DNA synthesiser (model 380A, Applied Biosystems) by Iris, Siena, Italy. The first primer, PTpl, spanned bases 307-332, roughly 200 bases upstream from the ATG codon for the S1 toxin subunit; the second primer, PTp2, overlapped the -10 regulatory box and spanned bases 497-469. The two primers defined a 191-bp DNA fragment.

\section{Controls}

To control for contamination, a water sample and one sample containing Tris- $\mathrm{HCl}$ and proteinase $\mathrm{K}$ were used as negative controls in every assay. As positive control, a sample containing $10 \mu \mathrm{l}$ of a heated suspension of $B$. pertussis ATCC 9797 (18-323) was run in parallel. To control for the presence of inhibitory substances in the aspirates, a fragment of DNA (see below) was used as an internal control in every sample.

\section{Construction of the internal control}

The construction of the DNA fragment to be used as the internal control is shown in Fig. 1. This fragment was generated by a deletion of $26 \mathrm{bp}$ from the 191-bp amplification product of $B$. pertussis. Four different primers were used to generate a 165-bp fragment. PTp1 and PTp2 defined the 191-bp fragment; a further primer, PTp3 (23 bp), was synthesised from an internal sequence of the 191-bp fragment. The last primer (PTp4) was obtained by synthesising together the sequences PTpl (modified by adding a Bam HI restriction site at the $5^{\prime}$ end) and PTp3. Primers PTp2/BamHI (PTp2 modified by adding a BamH1 site) and PTp3 were used in the first-run PCR to obtain a 133-bp DNA fragment. This fragment was purified from contaminating primers and deoxynucleotides by Centricon 100 (Amicon Inc., Beverly, MA, USA) and used in a second-run PCR, with primers PTp4 and PTp2/Bam HI, to obtain the 165-bp fragment. The amplification product was then isolated from the gel with Gene Clean (Bio 101, La Jolla CA, USA). After digestion with $B a m \mathrm{HI}$, the fragment was inserted into a plasmid vector PUC18 to obtain a recombinant plasmid pRP165 harbouring a 165-bp fragment flanked by primers PTp1 and PTp2.

To determine the detection limit in the PCR assay of the 165-bp fragment, several dilutions of the recombinant plasmid pRP165 were tested together with a $B$. pertussis-positive aspirate with the same amplification conditions as used for the 191-bp fragment. To avoid competition in the amplification reactions between the 191-bp and 165-bp fragments, double amounts of primers and deoxynucleotides were used. In these conditions the 165-bp fragment could be detected on agarose gels down to $c$. $1 \mathrm{fg}$ and could be clearly

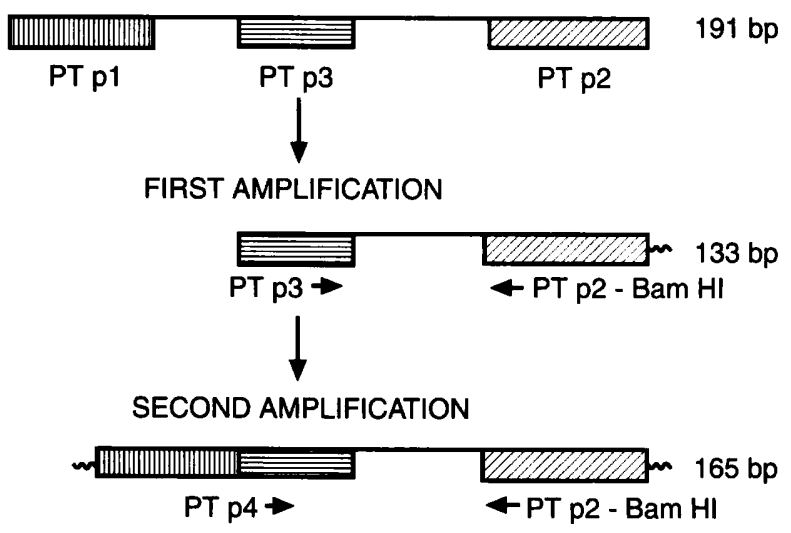

Fig. 1. Schematic representation of the construction of the internal control. The primers PTp1 and PTp2 define the 191-bp fragment. PTp3 and PTp2/Bam HI amplified the 133-bp fragment; PTp4 and PTp2/Bam HI generated the 165-bp fragment used as internal control. 
distinguished from $B$. pertussis-specific amplification products. Routinely, PCRs were performed in the presence of $30 \mathrm{fg}$ of $\mathrm{pRP} 165 \mathrm{DNA}$.

\section{PCR assay}

The reaction mixture consisted of $20 \mu$ of NPA extract, $200 \mu \mathrm{M}$ deoxynucleoside triphosphates (Perkin Elmer-Cetus), $20 \mathrm{pmoles}$ of each primer, 2.5 units of Taq DNA polymerase (Perkin Elmer-Cetus), $10 \mathrm{mM}$ Tris- $\mathrm{HCl}, 50 \mathrm{mM} \mathrm{KCl}, 1.5 \mathrm{mM} \mathrm{MgCl}_{2}$ and gelatin $1 \mathrm{mg} /$ $\mathrm{ml}$. Amplification was performed in a Perkin ElmerCetus 9600 instrument for 35 cycles with the following conditions for each cycle: denaturation $95^{\circ} \mathrm{C}(1 \mathrm{~min})$, annealing $66^{\circ} \mathrm{C}(1.5 \mathrm{~min})$ and elongation $72^{\circ} \mathrm{C}(2 \mathrm{~min})$.

\section{Detection of PCR products}

The reaction products were resolved on agarose $3 \%$ gels (3:1 Nusieve:agarose; FMC BioProducts, Rockland, ME, USA; BioRad, Milan, Italy) containing ethidium bromide $500 \mu \mathrm{g} / \mathrm{ml}$, and visualised under UV illumination. Reaction products were also detected by Southern blotting of the resolved gel [24]. DNA was denatured by soaking the gel for $30 \mathrm{~min}$ in $1.5 \mathrm{M} \mathrm{NaCl}$, $0.5 \mathrm{~N} \mathrm{NaOH}$ with constant agitation. The gel was then rinsed in de-ionised water, and neutralised in a solution of $1 \mathrm{M}$ Tris, $1.5 \mathrm{M} \mathrm{NaCl}(\mathrm{pH} \mathrm{7.4)}$ at room temperature for $15 \mathrm{~min}$. The DNA fragments were blotted on to Hybond-N nylon membranes (Amersham) by capillary transfer with $20 \times \mathrm{SSC}$ buffer $(3 \mathrm{M} \mathrm{NaCl}, 0.3 \mathrm{M}$ sodium citrate, $\mathrm{pH} 7.0$ ). The DNA was bound to the nylon membrane by UV cross-linking. The membrane was incubated in a pre-hybridisation solution $(5 \times$
SSC, blocking reagent $1 \%$ provided by Boehringer Mannheim, N-laurylsarcosine $0.1 \%$, SDS $0.02 \%$ ) for $60 \mathrm{~min}$ at $68^{\circ} \mathrm{C}$ to block non-specific nucleic acid binding sites. The hybridisation procedure was performed overnight with, as probe, $100 \mathrm{ng}$ of the 191-bp fragment labelled in PCR cycles in which dTTP was replaced with digoxigenin 11-dUTP [25]. Finally, the membrane was washed twice at $68^{\circ} \mathrm{C}$ in SDS $10 \%$ and $20 \times$ SSC to remove unbound probe. Digoxigenin detection was performed as recommended by the manufacturer (Boehringer, Mannheim, Germany).

\section{Results}

\section{Sensitivity and specificity}

To evaluate the sensitivity of the reaction, PCR was performed on serial dilutions (from $10^{8}$ to $10^{1} \mathrm{cfu} / \mathrm{ml}$ ) of heated suspensions of $B$. pertussis ATCC 9797 (18323). The presence of the amplified 191-bp fragment on agarose gels prepared from the suspensions of $B$. pertussis was detected down to about 10 bacteria (Fig. 2). The PCR assay gave a 191-bp product with all 40 clinical isolates of $B$. pertussis. The amplification product was never detected in any sample containing bacteria other than $B$. pertussis. The strains used to test the specificity of the two primers PTp1 and PTp2, are listed in Table 1.

\section{PCR on NPAs}

The 681 NPAs were obtained from children with a mean age of 10 months (range 1-26 months). At the time of sampling, the mean duration of cough was 10

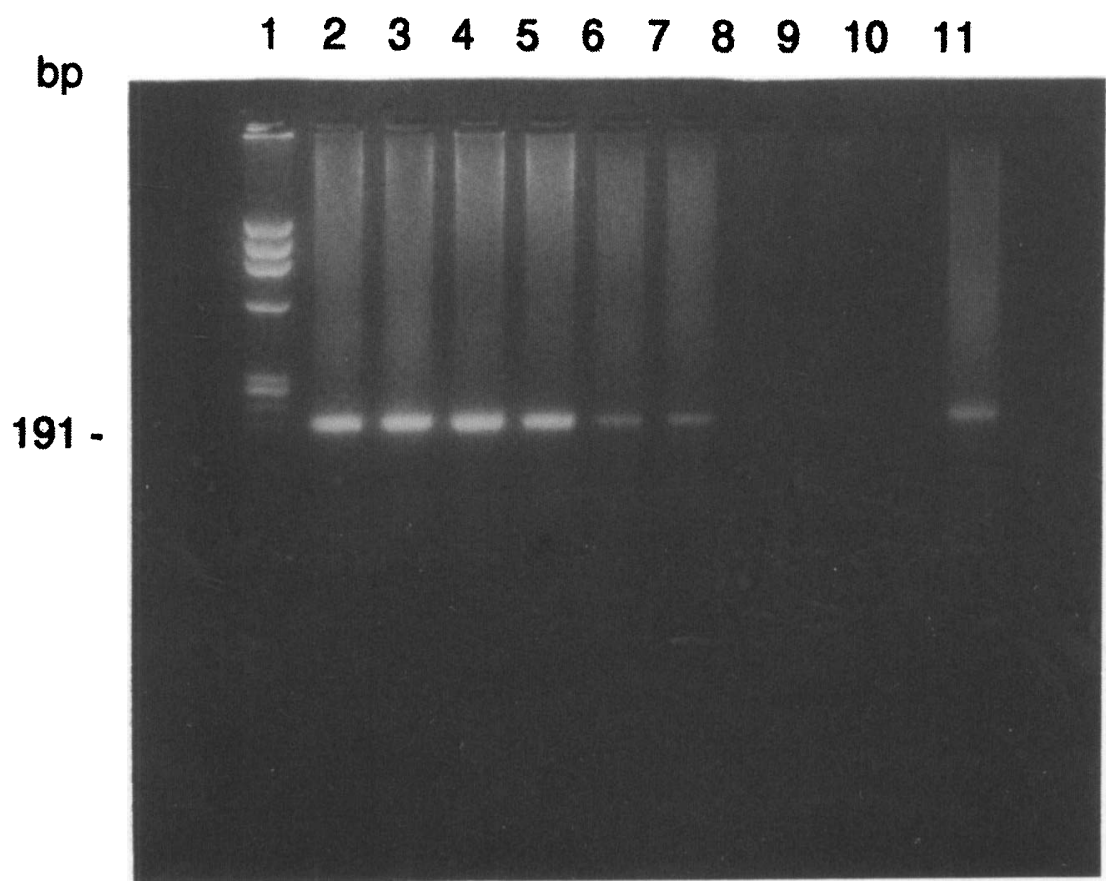

Fig. 2. Sensitivity of detection of $B$. pertussis by PCR. Lane 1, mol. wt marker pBR322 DNA-MspI Digest (New England-Biolabs); 2-9, amplification of the 191-bp fragment from $10^{8}$ to $10^{1} \mathrm{cfu} / \mathrm{ml}$; 10, negative control; 11, positive control. 
Table 1. Bacterial strains used in the PCR assay

\begin{tabular}{lc}
\hline \multicolumn{1}{c}{ Bacterial species } & Number of strains \\
\hline B. pertussis & 40 \\
B. parapertussis & 34 \\
B. bronchiseptica & 3 \\
Neisseria lactamica & 1 \\
Haemophilus influenzae & 1 \\
Klebsiella spp. & 1 \\
Pseudomonas spp. & 1 \\
Streptococcus spp. & 1 \\
Proteus vulgaris & 1 \\
Staphylococcus aureus & 1 \\
Escherichia coli & 1 \\
\hline
\end{tabular}

days with a range of $1-48$ days; $65 \%$ of the aspirates were collected within 10 days from the beginning of the cough.

Table 2 shows the results obtained by culture and PCR from the 681 aspirates. PCR identified 104 positive

Table 2. Detection of $B$. pertussis in nasopharyngeal aspirates by PCR compared with detection by culture

\begin{tabular}{lccc}
\hline & \multicolumn{2}{c}{ Culture result } & \\
\cline { 2 - 3 } \multicolumn{1}{c}{ PCR result } & Positive & Negative & Total \\
\hline Positive & 88 & 16 & 104 \\
Negative & 5 & 572 & 577 \\
Total & & 588 & 681 \\
\hline
\end{tabular}

aspirates compared with 93 by culture. Sixteen positive samples were detected exclusively by PCR. All culturepositive samples and 13 of 16 positive exclusively by PCR were clearly detected on agarose gels without Southern blotting and hybridisation. Five of 93 culture positive samples were negative by PCR. In one of the five culture positive, PCR negative aspirates the lack of amplification of the internal control (165-bp fragment) suggested the presence of inhibitory substances in the sample. Fig. 3 shows PCR amplification products obtained from three positive aspirates and from five PCR negative, culture positive samples. The 191-bp and 165-bp fragments were clearly detected in positive samples (lanes 2, 3 and 8). Lanes 4, 6, 7 and 9 show PCR negative aspirates in which only the internal control was detected. Lane 5 shows the sample without amplification of the internal control. Some characteristics of PCR positive, culture negative cases compared with culture positive cases are given in Table 3 . Nine (56\%) of 16 PCR positive, culture negative aspirates were collected later than 10 days from the beginning of the cough compared to $23(25 \%)$ of the 93 culture positive samples. Overall, $33 \%$ of children received antibiotics before sampling, with the same percentage among PCR positive, culture negative (31\%) and culture positive cases (30\%). A striking difference was observed in the duration of the antibiotic treatment before sampling between the two groups: a mean duration of 4 days for cases detected by culture versus 9 days for those detected only by PCR.

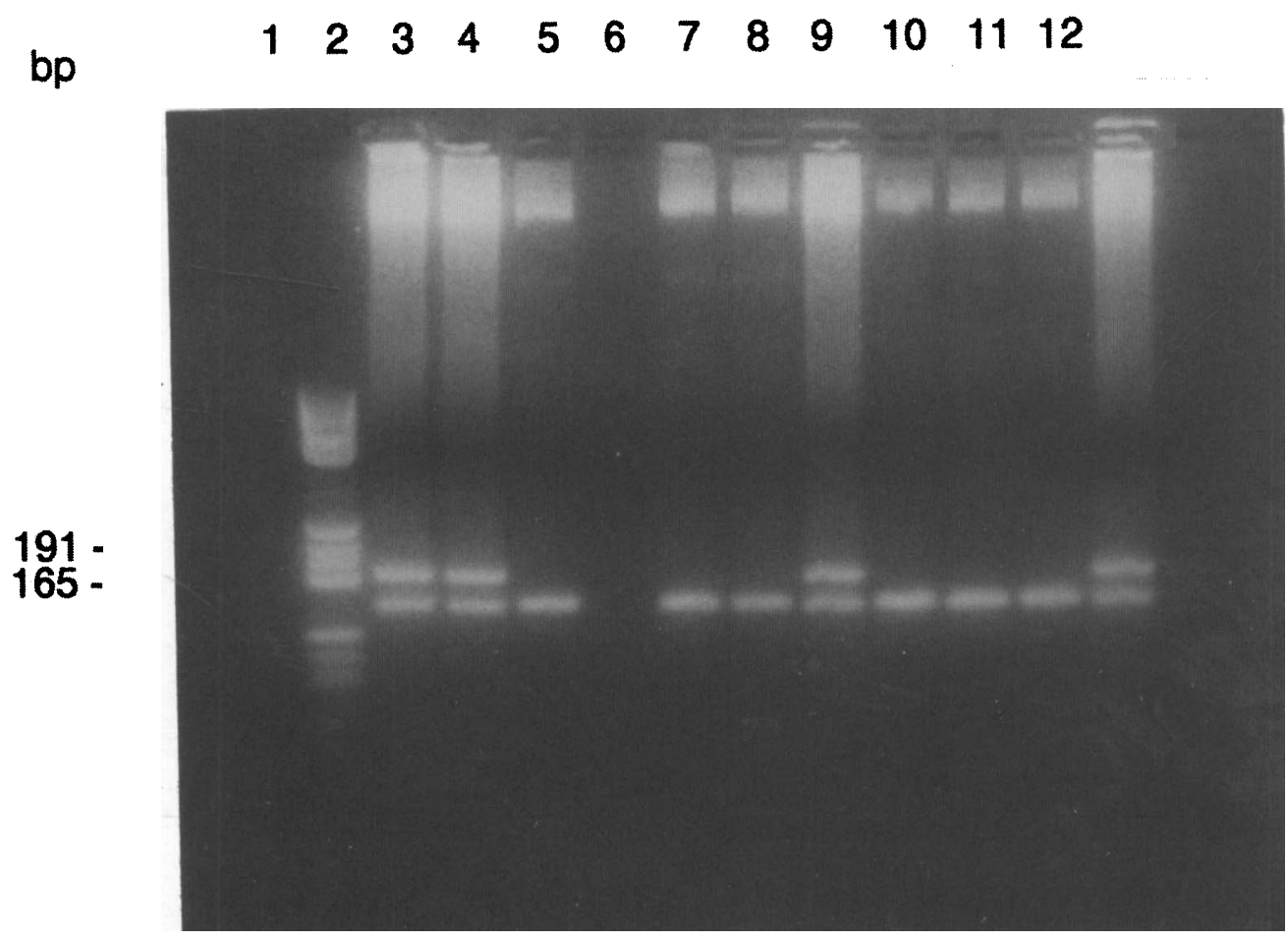

Fig. 3. Agarose gel electrophoresis of PCR amplified products from NPAs. Lane 1, DNA mol. wt marker V (Boehringer Mannheim); 2,3,8, positive aspirates; 4,6,7,9, negative aspirates; 5 , inhibitory sample; 10,11 , negative controls; 12 , positive control. The sizes of the amplified DNA fragments are indicated on the left. 
Table 3. Clinical characteristics of PCR positive, culture negative versus culture positive cases

\begin{tabular}{|c|c|c|c|c|c|c|}
\hline \multirow[b]{2}{*}{$\begin{array}{l}\text { Detection } \\
\text { method }\end{array}$} & \multirow[b]{2}{*}{$\begin{array}{c}\text { Number of } \\
\text { cases }\end{array}$} & \multicolumn{2}{|c|}{$\begin{array}{c}\text { Number }(\%) \text { of samples } \\
\text { collected after }\end{array}$} & \multicolumn{2}{|c|}{$\begin{array}{l}\text { Antibiotic treatment } \\
\text { before sampling }\end{array}$} & \multirow{2}{*}{$\begin{array}{l}\text { Number }(\%) \\
\text { with length } \\
\text { of cough } \\
\leqslant 14 \text { days }\end{array}$} \\
\hline & & $\begin{array}{l}\leqslant 10 \text { days } \\
\text { of cough }\end{array}$ & $\begin{array}{l}>10 \text { days } \\
\text { of cough }\end{array}$ & $\begin{array}{l}\text { Number }(\%) \\
\text { of cases }\end{array}$ & $\begin{array}{l}\text { Mean duration } \\
\text { (days) }\end{array}$ & \\
\hline PCR positive only & 16 & $7(44)$ & $9(56)$ & $5(31)$ & 9.6 & $5(31.2)$ \\
\hline Culture positive & 93 & $69(74)$ & $24(26)$ & $28(30)$ & 4.4 & $1(1.1)$ \\
\hline
\end{tabular}

There was a trend towards a history of less severe clinical symptoms in patients detected exclusively by PCR: one $(1.1 \%)$ of 93 culture positive patients and five $(31.2 \%)$ of 16 patients detected only by PCR showed mild symptoms. These cases had a history of cough for $<14$ days. The mean duration of cough among PCR positive, culture negative cases was 33 days and among culture positive cases, 75 days.

\section{Discussion}

In recent years, PCR has been suggested as a suitable method to detect $B$. pertussis, the principal advantages being the possibility of reducing the diagnostic time and improving diagnostic sensitivity [6-16]. Recently, recommendations for the use of PCR for the diagnosis of $B$. pertussis have been proposed. It has also been stressed that the ongoing trials of acellular pertussis vaccines represent an excellent opportunity for the evaluation and the validation of this methodology [18]. In Italy, a randomised double-blind controlled trial of pertussis vaccines has been conducted. An infant population of c. 15000 children was vaccinated and followed up for a period of 2.5 years. This trial allowed us to make an extensive comparison of results obtained by PCR and by culture in detecting $B$. pertussis infections.

The B. pertussis genomic region chosen for the amplification in the present study detected $B$. pertussis and no other Bordetella spp. or other bacterial strains tested. The sensitivity was validated by positive results for all B. pertussis strains tested and by positive results in $95 \%$ of culture positive aspirates. False-positive or false-negative results may represent a limit of the procedure and, therefore, rigorous controls must be pursued [18]. In this study, coded positive and negative samples were run in each assay. Furthermore, an internal control was added as a test of the performance of the assay. The use of the internal control allowed discrimination between false negative results due to substances inhibiting DNA amplification and true negative results. The rationale behind the choice of the internal control proposed was that it works with the same set of $B$. pertussis specific primers.

The study demonstrated that two primers identifying a DNA fragment located in the regulatory region of the pertussis toxin operon were sufficiently specific and sensitive to detect routinely $B$. pertussis in clinical aspirates. A total of 104 positive aspirates was identified by PCR whereas 93 were diagnosed by culture. Sixteen cases were detected exclusively by PCR. Southern blot and hybridisation analysis revealed three cases whose signals were too weak to be detected on agarose gel. Five of 93 culture-positive cases were PCR negative.

In one of these samples the internal control also was not detected, underlining the importance of including an internal control in the PCR assay. The culture positive, PCR negative results, not explained by the presence of inhibitors in the sample, may be due to the presence of few bacteria in the sample itself. Indeed, in these four cases, only two or three colonies grew on the charcoal agar plates inoculated with the aspirates. This result is in agreement with those of Ewanowich et al. [26]. In nine $(56 \%)$ of 16 PCR positive, culture negative cases, the timing of aspirate collection was later than 10 days from the beginning of cough, compared with $25 \%$ of culture positive episodes. This result stresses again the necessity of the early collection of samples for diagnosis by culture.

The PCR method appears to be more sensitive than culture for detecting $B$. pertussis in patients treated with antibiotics, as expected [10]. This study provides information on the influence of the length of treatment on detection by culture and PCR. The mean duration of therapy was 4 days for antibiotic-treated cases detected by culture versus 9 days for those detected by PCR. PCR proved to be better than culture in detecting $B$. pertussis in patients with mild symptoms (cough for $<14$ days). This clinical picture may often be present in vaccinated patients and detection of $B$. pertussis is useful to determine the influence of the vaccine on $B$. pertussis infection [27].

To conclude, the PCR technique described has proved to be a rapid, specific and sensitive method for the diagnosis of pertussis, and especially useful for overcoming culture failures due to the timing of sample collection and the use of antibiotics. This technique also appears to be more sensitive than culture in detecting $B$. pertussis in patients with mild disease.

We acknowledge the excellent technical assistance of Manuela Bottone and Tonino Sofia. This work was supported in part by grant no. AI 25138 from the National Institutes of Health, USA. 


\section{References}

1. Onorato IM, Wassilak SGF. Laboratory diagnosis of pertussis: the state of art. Pediatr Infect Dis J 1987; 6: 145-151.

2. Mertsola J, Kuronen T, Turunen A, Viljanen MK, Ruuskanen O. Diagnosis of pertussis. $J$ Infect $1984 ; 8$ : 149-156.

3. Lawrence AJ, Paton JC. Efficacy of enzyme-linked immunosorbent assay for rapid diagnosis of Bordetella pertussis infection. J Clin Microbiol 1987; 25: 2102-2104.

4. Viljanen MK, Ruuskanen O, Granberg C, Salmi TT. Serological diagnosis of pertussis: IgM, IgA and IgG antibodies against Bordetella pertussis measured by enzyme-linked immunosorbent assay (ELISA). Scand $J$ Infect Dis 1982; 14: 117-122.

5. Mertsola J, Ruuskanen O, Kuronen T, Viljanen MK. Serologic diagnosis of pertussis: comparison of enzyme-linked immunosorbent assay and bacterial agglutination. J Infect Dis 1983; 147: 252-257.

6. Douglas E, Coote JG, Parton R, McPheat W. Identification of Bordetella pertussis in nasopharyngeal swabs by PCR amplification of a region of the adenylate cyclase gene. $J$ Med Microbiol 1993; 38: 140-144.

7. Glare EM, Paton JC, Premier RR, Lawrence AJ, Nisbet IT. Analysis of a repetitive DNA sequence from Bordetella pertussis and its application to the diagnosis of pertussis using the polymerase chain reaction. $J$ Clin Microbiol 1990; 28: 1982-1987.

8. Houard S, Hackel C, Herzog A, Bollen A. Specific identification of Bordetella pertussis by polymerase chain reaction. Res Microbiol 1989; 140: 477-487.

9. Li Z, Jansen DL, Finn TM et al. Identification of Bordetella pertussis infection by shared-primer PCR. J Clin Microbiol 1994; 32: 783-789.

10. Reizenstein E, Johansson B, Mardin L, Abens J, Möllby R, Hallander HO. Diagnostic evaluation of polymerase chain reaction discriminative for Bordetella pertussis, $B$. parapertussis, and B. bronchiseptica. Diagn Microbiol Infect Dis 1993; 17: $185-191$

11. Olcén P, Bäckman A, Johansson B et al. Amplification of DNA by the polymerase chain reaction for the efficient diagnosis of pertussis. Scand J Infect Dis 1992; 24: 339-345.

12. He Q, Mertsola J, Soini H, Skurnik M, Ruuskanen O, Viljanen MK. Comparison of polymerase chain reaction with culture and enzyme immunoassay for diagnosis of pertussis. $J$ Clin Microbiol 1993; 31: 642-645.

13. He Q, Mertsola J, Soini H, Viljanen MK. Sensitive and specific polymerase chain reaction assays for detection of Bordetella pertussis in nasopharyngeal specimens. $J$ Pediatr 1994; 124:
$421-426$.

14. Bäckman A, Johansson B, Olcén P. Nested PCR optimized for detection of Bordetella pertussis in clinical nasopharyngeal samples. J Clin Microbiol 1994; 32: 2544-2548.

15. Birkebaek NH, Heron I, Skjødt K. Bordetella pertussis diagnosed by polymerase chain reaction. APMIS 1994; 102: 291-294.

16. Lichtinghagen $R$, Diedrich-Glaubitz $R$, von Hörsten $B$. Identification of Bordetella pertussis in nasopharyngeal swabs using the polymerase chain reaction: evaluation of detection methods. Eur J Clin Chem Clin Biochem 1994; 32: 161-167.

17. McLafferty MA, Harcus DR, Hewlett EL. Nucleotide sequence and characterization of a repetitive DNA element from the genome of Bordetella pertussis with characteristics of an insertion sequence. J Gen Microbiol 1988; 134: 2297-2306.

18. Meade BD, Bollen A. Recommendations for use of the polymerase chain reaction in the diagnosis of Bordetella pertussis infections. J Med Microbiol 1994; 41: 51-55.

19. Musser JM, Hewlett EL, Peppler MS, Selander RK. Genetic diversity and relationships in populations of Bordetella spp. $J$ Bacteriol 1986; 166: 230-237.

20. Aricò B, Rappuoli R. Bordetella parapertussis and Bordetella bronchiseptica contain transcriptionally silent pertussis toxin genes. J Bacteriol 1987; 169: 2847-2853.

21. Aricò B, Gross R, Smida J, Rappuoli R. Evolutionary relationships in the genus Bordetella. Mol Microbiol 1987; 1: 301-308.

22. Regan J, Lowe F. Enrichment medium for the isolation of Bordetella. J Clin Microbiol 1977; 6: 303-309.

23. Walsh PS, Metzger DA, Higuchi R. Chelex 100 as a medium for simple extraction of DNA for PCR-based typing from forensic material. BioTechniques 1991; 10: 506-513.

24. Southern EM. Detection of specific sequences among DNA fragments separated by gel electrophoresis. J Mol Biol 1975; 98: $503-517$.

25. Lion T, Haas OA. Nonradioactive labeling of probe with digoxigenin by polymerase chain reaction. Anal Biochem 1990; 188: $335-337$

26. Ewanowich CA, Chui LW-L, Paranchych MG, Peppler MS, Marusyk RG, Albritton WL. Major outbreak of pertussis in Northern Alberta, Canada: analysis of discrepant direct fluorescent-antibody and culture results by using polymerase chain reaction methodology. $J$ Clin Microbiol 1993; 31: 1715-1725.

27. Schläpfer G, Senn HP, Berger R, Just $M$. Use of the polymerase chain reaction to detect Bordetella pertussis in patients with mild or atypical symptoms of infection. Eur $J$ Clin Microbiol Infect Dis 1993; 12: 459-463. 